\title{
Pós-estruturalismo, religião e democracia: notas sobre aportes teóricos do deslocamento do político para a subjetividade ${ }^{1}$
}

\author{
Josadac Bezerra dos Santos*
}

\begin{abstract}
R esumo: O texto aborda a questão da democracia com base no conceito de democracia agonística de Chantal Mbuffe e focaliza o lugar do político como inerente à cultura. Sugere, como consequiência, a análise de situaçães sociais de politização da sexualidade e da vida, no campo religioso.

Palavras-chave: democracia, religião, subjetividade.
\end{abstract}

Introdução

Gostaria de expor ao leitor a seguinte questão: que espaço ocupa hoje a politização da subjetividade na esfera religiosa no debate sobre a democracia ou, mais especificamente, sobre uma determinada concepção de democracia? Quase sempre temos a tendência de generalizar o conceito de democracia, pressupondo-o em um sentido único e universal. G ostaria de trabaIhar com esse conceito, mas afirmando a sua natureza contingente e relativa, sustentando-se hegemonicamente em uma determinada situação histórica apenas de forma precária e, no nosso caso, pontual. Para isso, énecessário reconhecer que a sociedade está pulverizada por discursos de determinados atores sociais, individuais ou coletivos, que constituem pontos nodais nos quais preval ece um sentido de confronto e de opressão ou de inexistência de liberdade e/ou de igualdade,

\footnotetext{
* Professor de Ciência Política da Universidade Federal de Sergipe, doutorando de Sociologia do Programa de PósGraduação em Sociologia da Universidade Federal de Pernambuco e bolsista do CN Pq.

1. U ma primeira versão deste texto, e com outro título, foi apresentada em uma mesa-redonda no I Seminário Nacional Pós-Estruturalismo, Sociedade e Política no Brasil, realizado em Recife, em 8 de julho de 2004.
}

em que um conceito formal de democracia aquele que se convenciona chamar de "E stado de direito" - não responde às tensões causadas pela busca de liberdade ou igualdade por parte de tais atores.

Como verá o leitor, um exemplo de tais situações se reconhece no processo de politização de questões da contemporaneidade, como os que se originam numa determinada face do feminismo, aquele que discute o papel da mul her dentro e fora da Igreja, levantando questões como a suposta submissão natural da mulher ao homem, a submissão do seu corpo aos caprichos masculinos e a própria condição de uma ordem patriarcal dominante, em que, em nome de D eus e de val ores religiosos, se mantém a mulher em uma clara condição de inferioridade diante do homem.

U ma outra fonte de tais tensões está nas questões oriundas do conflito em relação ao direito ao aborto. A qui a tensão gira em torno da autonomia das mulheres com relação a seus corpos, mas também há a questão da vida: a reflexão sobre se há aí um processo de desrespei to a um valor sagrado e intrínseco à própria ordem natural da existência biológica, mesmo que em um nível elementar. A vida como um 
valor e, portanto, um direito universal sobre 0 qual ninguém tem o direito de interromper evidencia-se também na controvérsia sobre a eutanásia. N esse último sentido, nem mesmo 0 extremo sofrimento e, conseqüentemente, a perda de qual quer sentido de dignidade da vida justificariam a autorização do Estado e o reconhecimento da lei, para que tal ato seja praticado com liberdade pelos profissionais da saúde.

Para concluir a nossa lista de exemplos, resta-nos uma referência à questão da politização da sexualidade e, mais especificamente, a questão da homossexualidade ou homoafetividade. A qui a controvérsia gira em torno de uma possível desconstrução política da legitimidade única das relações heterossexuais. Desconstruindo-se uma proposição epistemológica que leve em conta o fato dado pela natureza, e desconsiderando-se as diferenças corporais entre o homem e a mul her, transportase a sexualidade para um plano unicamente cultural, chegando-se assim à essência da controvérsia inerente à politização da sexualidade. De um lado, aqueles que a defendem como um dom de Deus e, de outro, os que a encaram como um dado relativo da cultura.

$\mathrm{N}$ aturalmente, estas não são as únicas questões a colocar em cheque a democracia. Outras questões tais como o dilema ecológico, as disputas raciais na Europa, as demandas políticas oriundas das novas tecnologias, principalmente as que dizem respeito à manipulação genética, todas estas trazem consigo a marca de se situarem para além das fronteiras postas por um sentido tradicional da política, requerendo de nós uma reflexão sobre "o político", isto é, aquilo que há de antagônico em todas essas demandas, e a insuficiente capacidade da política em seu sentido tradicional em responder a essas novas situações sociais.

Como estaremos dando ênfase às dimensões do conflito que se originam na esfera religiosa ou que a ela dizem respeito por se tratarem de questões relativas à politização da vida, da sexualidade, da subjetividade e da cultura, pretendemos, em primeiro lugar, fazer uma referência à contemporaneidade do catolicismo, e a forma como este tem enfrentado a politização de temas como a sexual idade e a vida. Veremos, no entanto, que, embora esse segmento do espectro religioso brasileiro seja o mais expressivo, tanto numérica como culturalmente para o cenário religioso do B rasil, essas questões não se limitam ao catolicismo e sim ao campo cristão como um todo. Em segundo lugar, uma exposição sobre as possibilidades de um referencial teórico pós-estruturalista que leva em conta a politização da subjetividade tendo como base a cultura e, conseqüentemente, a religião, assim como a politização da vida e da sexualidade. Por fim, uma breve exposição das minhas próprias interrogações sobre esses fatos.

Para isso valho-me, inicialmente, de um texto recentemente publicado por M aria José R osado-N unes, intitulado " $O$ catolicismo sob o escrutínio da modernidade". ${ }^{2}$ Nesse ensaio, R osado-N unes demonstra-nos o que ela concebe como sendo "a agenda atual das relações da I greja Católica com a contemporaneidade brasileira", mostrando a dificuldade na qual se encontra a I greja Católica diante de temas tais como a homossexualidade e o aborto, só para citar duas demandas das mais relevantes.

Religião e política: expectativas frustradas ou rumos diferentes?

Referindo-se a Cândido Procópio Ferreira de Camargo e seu livro Católicos, protestantes, espíritas (1973), no qual o autor externa a esperança de que estudos empíricos do fenômeno religioso cristão venham a confirmar a hipótese de que "a tomada de consciência por via religiosa seria capaz de inspirar a participação mais ampla da população no delineamento de soluções econômicas, sociais e políticas do país" (Camargo, 1973, p. 16), R osado-N unes procura sustentar a tese segundo a qual houve, ao longo dos últimos vinte anos, um deslocamento do papel da I greja Católica no âmbito da sociedade brasileira, tirando-a de uma visibilidade pública de natureza política para um retorno aos templos. À I greja coube o papel de voltar-se para dentro de si mesma, seja em decorrência de um cenário nacional que mudou, seja por causa da guinada política e teológica conservadora imposta pelo pontificado de J oão Paulo II.

2. In: SOUZA, Beatriz Muniz \& DE SÁ MARTINO, Luís Mauro (Orgs.). Sociologia da religião e mudança social: católicos, protestantes e novos movimentos religiosos no Brasil. São Paulo: Paulus, 2004 
Esse deslocamento gerou, como principal conseqüência, 0 "aparecimento" de questões que antes não constituíam uma preocupação tão acentuada dentro da I greja, uma vez que havia uma harmonia política entre uma cultura cristã, humanista e tradicional característica da sociedade brasileira e as históricas posições da I greja em torno das questões relativas ao feminino, por oposição ao feminismo, à vida, por oposição ao aborto e à eutanásia, e a uma sexualidade calcada no fundamento epistemológico do fato dado, da natureza criada por Deus, que criou homem e mulher; e viu o Senhor que o que havia feito era bom!

$\mathrm{N}$ ão é, portanto, sem razão que escrevo a palavra "aparecimento" no parágrafo anterior entre aspas. Todas essas questões já estavam postas na doutrina da Igreja, e na sociedade brasileira em geral, há muito tempo. Na verdade, o que nos importa, do ponto de vista da abordagem teórico-metodológica no campo em que estamos inseridos, é o aparecimento de questões como estas acima enumeradas em um cenário contemporâneo; certamente uma decorrência da mobilização de forças sociais, notadamente, os movimentos feminista e o GL BT, ${ }^{3}$ sejam eles de natureza laica ou confessional. Em outras palavras, o que nos interessa entender é por que velhas conclusões doutrinárias, teológicas e epistemológicas ganham uma nova visibilidade neste momento. Que novos significados esses conflitos trazem?

Para Rosado-N unes (2004), as mudanças ocorridas no catolicismo têm um caráter de surpresa, na medida em que estas não eram esperadas, e representam uma mistura entre novos val ores de uma contemporaneidade global que questiona o papel da mulher e de sua autonomia, assim como a forma tradicional de ver a sexualidade. Diante dessa nova real idade, o tradicional ismo católico acaba se colocando em rota de colisão com as novas demandas. $\mathrm{Ou}$ seja, um distanciamento entre a I greja e a sociedade estabelece-se, e um confronto configura-se, levando Rosado-Nunes a propor a seguinte hipótese:

o trabalho da secularização e da conseqüente possibilidade de uma multiplicidade religiosa

3. A sigla significa $G$ ays, Lésbicas, B issexuais e Transgêneros. vasta, rica, curiosa e interessante - em todos os sentidos: para a pesquisa e para a experiência religiosa - mudou, ou está mudando fortemente a relação da sociedade, do papel dos fiéis com a I greja e com essa mesma religião. (RosadoNunes, 2204, p. 24)

Para a autora, essa hipótese implica duas conseqüências: primeiro, o que ela chama de "processo de dessacralização da instituição religiosa" (Rosado-N unes, 2004, p.24), isto é, a diminuição acentuada da importância da instituição I greja Católica como referência simbólica legítima quase única de espiritualidade cristã. Segundo, a forma como a sociedade civil reage às afirmações da Igreja Católica e de outras igrejas conservadoras no que se refere às questões da sexualidade e do espaço da mulher dentro e fora da I greja Católica e outras igrejas cristãs. Isso indica "que o trabal ho da cultura moderna - afirmação de valores, como as liberdades democráticas e a autonomia individual seja mais rápido e mais persuasivo sobre a sociedade do que se poderia supor" (RosadoN unes, 2004, p. 24).

Estou de acordo com essas premissas. Sobretudo a segunda, que nos fal a de uma situação nova, um novo momento das relações entre a esfera religiosa e a sociedade em geral. A crescentaria apenas que essa nova situação levanos ao reconhecimento de pontos nodais, nos quais confrontos específicos se configuram de modo a fazer surgir uma luta por um significado de liberdade que implique acomodar, ainda que temporariamente, um novo sentido de democracia.

U ma observação acurada dos fatos vai constatar, por exemplo, que o movimento prógay tende a interpretar como libertária a sua luta pela assunção pública de sua condição homoerótica, enquanto para aqueles movimentos que vêm na homossexualidade um transtorno espiritual, para dizer o mínimo, acreditam que liberdade é, exatamente, a superação do mito segundo o qual a homossexualidade é uma condição dada pela natureza (genética), ou pela cultura ou por qual quer outro fator, não importa. $M$ as que implique uma situação irreversível. A ssim, temos um mesmo signo abrigando dentro de si pelo menos dois significados opostos e concorrentes, excludentes até; mas até podendo, 
em alguns momentos, ser complementares. 0 fato é que a luta por uma fixação de um significado de liberdade revela um sentido de politização da subjetividade que alcança a esfera da cultura e da religião e pressiona, em um momento seguinte, o Estado.

$M$ as cabe-nos ainda responder à questão posta no título desta seção. Como RosadoNunes, também entendo que o que houve na sociedade brasileira nos últimos anos foi 0 surgimento de uma realidade social nova, que acabou por fazer vir à tona uma tensão entre a I greja e os novos movimentos sociais que politizam a sexualidade num nível nunca antes posto, assim como a politização da vida. De modo que seria impossível a autores de décadas atrás preverem esses novos e surpreendentes rumos, pelo menos, não nos moldes em que isso acabou acontecendo.

É preciso encarar os novos desafios e as novas fronteiras do social, em que o político se apresenta de forma diferente do que se esperaria normalmente. Os estudos sobre os chamados "novos movimentos sociais", presentes entre nós desde a década de 1970, já nos apontavam essa necessidade. ${ }^{4} \mathrm{~N}$ o entanto, a realidade social sempre nos traz algo novo, e novos desafios teóricos acabam impondo-se. É o quequeremos tentar expor na seqüência: ver o político em oposição, ou, senão em oposição, numa perspectiva diferente da política.

A política, em seu sentido tradicional, tem sido hoje alvo de questionamentos. $\mathrm{Nem}$ mesmo a histórica afirmação da limitação do poder do Estado na vida privada, na qual está, em princípio, a liberdade de crer e de exercer plenamente seu culto, ou expressar a sua fé através do uso desímbolos visuais e públicos, encontra-seisenta de questionamentos. Este, também, é hoje um espaço afetado por demandas da subjetividade, podendo-se encontrar nos jornais conflitos sociais que apontam nessa direção, como vimos no episódio recente dos símbolos religiosos em escol as públicas da França. ${ }^{5} \mathrm{~A}$ ssim, há, também,

4. Ver, entre muitos outros, a exposição a esse respeito feita por Doimo, 1995.

5. Uma lei aprovada pelo parlamento francês proíbe o uso de símbolos religiosos "ostensivos" em escolas públicas por um ano, em caráter experimental, para preservar a neutralidade religiosa do Estado. um questionamento da política na sua forma tradicional, uma suspeição de que as abordagens analíticas que a privilegiam não dêem conta das novas demandas. $D$ aí a necessidade da reflexão sobre "o político" como categoria de análise.

\section{"O político" e a religião}

Dois autores são centrais para o desenvolvimento desse conceito e sua aplicabilidade ao campo religioso. Chantal M ouffe (1996; 2003) e J oanildo A lbuquerque Burity (1997; 2001; 2002). M ouffe propõe a distinção entre "a política" e "o político". Embora a autora, aparentemente, faça uso al eatório das duas expressões em muitas ocasiões, ela estabelece uma distinção, sim, entre essas duas categorias. Para M ouffe, no projeto liberal, "a política" caracteriza-se por um sentido de consenso, isto é, a meta é encontrar uma situação de paz pela atenuação do conflito, imposta pela maioria, e fechar os olhos para pontos nodais de conflito no interior da sociedade. Para o que el a entende por "o político", ao contrário, o pressuposto é o dissenso, e o reconhecimento da legitimidade do dissenso como parte essencial à democracia. Isto porque "o político" pressupõe a existência de discursos alternativos concorrentes que se articulam, fazendo assim ef etuar-se um processo propriamente político que se insere no espaço da cultura (M ouffe, 1996, p. 69).

M ouffe ainda nos fala de um modelo de democracia que chama de "pluralismo agonístico", entendendo-se por essa expressão "um model 0 alternativo de democracia, mas apropriado às tarefas que nos confrontam hoje" (M ouffe, 2003, p. 15). Para uma compreensão adequada desse conceito, é necessário uma breve exposição sobre alguns pressupostos da autora. ${ }^{6}$ Primeiro, o que M ouffe chama de "inerradicabilidade do poder e do antagonismo" (M ouffe, 2003, p. 12). Isto é, todo ato de poder consiste na existência de antagonismo. I sso implica negar a possi bilidade de que a sociedade democrática possa ser concebida como uma sociedade capaz de realizar o sonho "de uma perfeita harmonia

6. Para um aprofundamento no pensamento de C. Mouffe e E. L aclau sobre esses pressupostos aqui resumidos, ver Hegemony \& socialist strategy: towards a radical democratic politics. London/New York: Verso, 1985. 
e transparência" (M ouffe, 2003, p. 14). Segundo, para M ouffe, "a objetividade social é constituída através de atos de poder" (M ouffe, 2003, p. 140). Sendo a objetividade social assim constituída, "qual quer objetividade social é definitivamente política" (M ouffe, 2003, p. 14) e "implica que se tem de mostrar os traços da exclusão que governa sua constituição" (M ouffe, 2003, p. 14). 0 terceiro pressuposto de $M$ ouffe é que o poder não pode ser entendido como uma "relação externa que acontece entre duas identidades préconstituídas, como pressupõe a proposta liberal de democracia, mas antes como constituintes das próprias identidades" (M ouffe, 2003, p. 14). A ssim, a tarefa de uma sociedade democrática não é a defesa do direito de identidades préconstituídas e, sim, o direto à construção das próprias identidades em si, ainda que "num terreno precário e sempre vulnerável" (M ouffe, 2003 , p. 14). Final mente, um último pressuposto que queremos salientar é 0 da "desuniversal ização dos sujeitos políticos" (M ouffe, 2003, P. 14). Essa desuniversalização tem para M ouffe dois alvos: o rompimento com toda forma de essencialismo, que na visão da autora está na base de toda a sociologia moderna e no pensamento liberal, e a crítica ao pós-modernismo fragmentário. Isto porque

cada identidade social é perfeitamente definida no processo histórico de deslocamento do ser, mas também com o seu oposto diametral: um certo tipo de extrema fragmentação pósmoderna do social, que recusa dar aos fragmentos qualquer identidade relacional. (M ouffe, 2003, p. 14-15)

Passemos a verificar os argumentos em relação ao modelo al ternativo de democracia a que M ouffe se refere. Se partirmos, então, da percepção de que "o político" constitui uma referência ao conflito inerente ao convívio dos seres humanos e, conseqüentemente, a formas de antagonismos que se encontram por toda parte no interior das sociedades e, de outro lado, que "a política" é uma referência "ao conjunto de práticas, discursos e instituições que procuram estabelecer uma certa ordem, e organizar a coexistência humana em condições que são sempre conflituosas, porque afetadas pela condição 'do político'" (M ouffe, 2003, p. 15), entendemos que existe aí uma relação de causalidade, na medida em que a segunda deve a sua razão de ser à primeira. Isso reforça a idéia de que toda ação social ou toda identidade social é, em qualquer nível, uma relação política que se constrói na própria feitura da referida identidade. É com base nesse paradigma que M ouffe apresenta a questão da problemática central da democracia na contemporaneidade.

Sendo, para a política, tarefa primordial a construção de uma identidade coletiva, que se expressa, por exemplo, através de um partido político ou de uma representação sindical, ou seja, a construção de um "nós" que se afirma em oposição a um "eles", a questão central da política é, na visão de uma política tradicional, a busca da superação da distinção nós/eles. Para M ouffe, e vários outros autores como E. L aclau, J. Burity, J. Torfing, por exemplo, a questão central não é a superação da distinção nós/eles e, sim, uma nova forma de abordar ou de trabal har essa distinção. Essa nova forma deve levar em conta, sobretudo, o direito do outro à sua própria existência em um campo de significação que resulta de uma diversidade de posições de sujeitos, discursos e identidades em construção, que procuram disputar entre si um "ponto de convergência entre objetividade e poder", o qual Mouffe chama de hegemonia (cf. 2003, p.14). Essa nova forma também implica uma maneira distinta de ver, no campo da política, a relação com o "outro". A pesar do antagonismo, o outro deve ser visto não como inimigo, mas como adversário. Esse modo de enxergar o conflito confere um sentido de legitimidade democrática e de realismo não presentes nas formas tradicionais de percepção do conflito político. De acordo com M ouffe,

0 adversário é al guém com cujas idéias iremos lutar, mas cujo direito de defender tais idéias não devemos questionar, isto porque 0 adversário é um inimigo legítimo, um inimigo com quem temos em comum uma adesão partil hada aos princípios ético-políticos da democracia. $M$ as nossa divergência diz respeito ao seu significado e implantação, e não a algo que poderia ser resolvido através de deliberação e discussão racional. (M ouffe, 2003 p. 16) 
Tendo como referência esse enfoque ou pressuposto, isto é, o respeito mútuo e de princípios ético-políticos, M ouffe sedimenta seu argumento a favor de um modelo agonístico de democracia, no qual o contraponto com a doutrina liberal passa pela negação da necessidade de renúncia às paixões, tema corrente nos clássicos pensadores liberais que, em nome e a favor da razão, defenderam essa exclusão. M ouffe, ao contrário, resgata- 0 ao dizer que

a tarefa primária da política não é eliminar as paixões, nem relegá-las à esfera privada para tornar possível o consenso racional, mas para mobilizar aquel as paixões em direção à promoção do desígnio democrático. (M ouffe, 2003, p. 16)

U ma outra conclusão importante de M ouffe é a de que uma democracia do tipo agonístico é uma resposta alternativa ao modelo de representação simbólica que concebe a sociedade como um organismo, o que implica uma visão integracionista da organização social. A alternativa consiste na proposição de um model o do tipo "consenso conflitual", isto é, um pluralismo democrático que valorize o dissenso, ao permitir o surgimento de instituições que exteriorizem posições antagônicas, podendo-se falar, como assinala M ouffe, em vários projetos de cidadania diferentes (M ouffe, 2003, p. 17).

E mbora de modo incompleto, o que até aqui foi dito sobre "o político" parece-nos suficiente para entrar nas questões de natureza mais específica no que se refere ao religioso, ainda no nível teórico.

Inicialmente, diríamos que o enfoque da religião, no contexto dessa perspectiva pósestruturalista da política, leva em conta a noção de que não se faz qualquer distinção entre cultura e religião, tomando-se sempre a segunda como parte inerente à primeira e concluindo-se, desde já, que tudo o que seja possível dizer sobre a politização da religião, ou de aspectos da subjetividade que tenha na religião o seu espaço social, também se diria com relação à cultura.

Um enfoque sociológico da religião no âmbito desse referencial teórico leva também em conta que 0 atual quadro do papel da religião no $B$ rasil e no mundo diferencia-se do que se observava em tempos passados, na medida em que hoje, como sintetiza B urity, se desenha um processo de desprivatização e publicização do religioso (B urity, 2001, p. 100). Isto significa um deslocamento de fronteiras, no qual o que antes não era alvo das ações e leis do Estado passa a ser, como no caso da legislação sobre os símbolos de fé em lugares públicos na França, e 0 que antes constituía um assunto totalmente privado é publicizado, como as questões da legitimação religiosa das relações homoeróticas, por exemplo.

Outro ponto importante é a tendência contemporânea à "desinstitucional ização" dos espaços religiosos. Não se valorizam mais as amarras das estruturas eclesiásticas. Esse fato leva a uma ressignificação do religioso, do sentimento de pertencimento religioso, que passa a ser entendido como uma atitude de espírito, um sentimento de liberdade para expressão de júbilos irracionais, "não mais uma herança, mas uma opção" (Prandi, Folha de São Paulo, 26/ 12/99), e não mais o lógico da confessionalidade formal e do sentimento de pertencimento exclusivo, inclusive burocrático. A inda mais se levando em conta o seu emprego para outras dimensões do social, como ocorre com o movimento Nova Era, assim como a apropriação dessa identidade por agentes que, em princípio, não deveriam mostrar qualquer interesse em utilizá-la, como éo caso do movimento feminista, com sua ONG Católicas pelo Direito de Decidir.

Reconhecendo-se tal flexibilização, é relevante, como dissemos anteriormente, procurar entender: por que a religião acabou tornando-se um espaço de real importância em questões da homossexualidade, aborto e outras relativas à vida, abrigando, em seu interior, posições aparentemente inesperadas?

No bojo de uma discussão sobre até que ponto ou de que forma expressões religiosas diversas influenciam ou não em processos e valores democráticos, B urity (2002) levanta 0 problema da contemporaneidade do campo eclesiástico cristão, situando-o na contemporânea questão da relativização entre o público e o privado. Q uestão esta que, creio eu, está no centro dos debates relativos à descriminal ização e à legalização do aborto e da eutanásia, assim como a questão da homossexualidade e do 
feminismo, embora não se fale exatamente nesses termos, e sim da maior necessidade de "liberdade" para as mulheres ou para os homossexuais (Burity, 2002, p. 31). Se, por um lado, a publicização de visões sobre questões sociais causaram, como afirma Burity, reações de natureza político-teológica que desagradaram os que as colocaram nesse patamar, a publicização da sexual idade e da vida na contemporaneidade, e em dimensões nunca antes vistas, mais ainda. 0 que antes era considerado de fórum íntimo, ou estava velado por val ores sobre os quais não restavam dúvidas, causa ainda mais reações e mais antagonismos em relação àquel es sujeitos, pessoais ou coletivos, que assim se expunham.

A proposta do autor é, então, que nos aproximemos da questão através dos debates ou teorizações em torno da cultura política, e mais especificamente da cultura política democrática, ou "da politização contemporaneamente experimentada pelo conceito de cultura política" (Burity, 2002, p. 32). Burity enumera como questões que antecedem, e que, de certa forma, são a causa da politização com base na cultura, a crise de interpretação crítica que se abate sobre o marxismo, mas não exclusivamente sobre essa corrente de pensamento, e a crise dos projetos de regulação ou de transformação social substantiva pela via da politização do social dos anos 80 (B urity, 2002, p. 33). Não temos como expor aqui os detal hes dos argumentos do autor. $M$ as é preciso reconhecer com B urity que

no bojo da efervescência que acompanhou a débâcle vê-se a percepção de que movimentos e processos culturais teriam um lugar importante seja como 'atmosfera' das mudanças ocorridas, seja como chave explicativa para as mesmas. (Burity, 2002, p. 34)

o que importa é levar em conta que a cultura passa a ser, na ótica de vários autores, 0 lugar onde se "objetiva" o social e onde a análise de cada situação cultural específica, ou um conjunto de elementos culturais, torna-se o foco ou o elemento de estudo no qual se encontram sentidos para participantes e implicados. Para Somers \& Gibson, a especificidade dessa priorização da cultura no âmbito do marco teórico aqui destacado é que o elemento distintivo desta reformulação está na posição de que a lógica de uma estrutura cultural corresponde a uma rede relacional de sentido, de modo que os diversos elementos constitutivos do conjunto somente adquirem sentido pela sua aproximação/oposição um em relação aos outros. (Somers \& Gibson, apud Burity, 2002, p. 35)

Com base em um pressuposto que considera a estrutura cultural uma rede relacional de sentidos, parece-me suficiente retomar a idéia de que tal proposição deixa claro o deslocamento aqui proposto. Não só no sentido da autonomia da cultura em relação a uma base material, ou a um sentido de subjetividade que se limite à atribuição de sentido dada pelos sujeitos pura e simplesmente, mas também no que diz respeito à política. A politização da cultura elou de seus elementos constitutivos sinaliza na direção da construção de um marco analítico que nos permite abordar, de modo convincente, questões conflituosas como as que se encontram na ordem do dia da esfera religiosa: a vida e a sexualidade.

Em suas conclusões sobre a politização da cultura, Burity propõe-nos três questões que podemos considerar sínteses da relação religião, cultura, política e democracia. E o faz no seguinte questionamento: como a mudança no campo religioso expressa (a) um deslocamento para al ém da esfera estatal; (b) a retomada de ênfases éticas, e (c) a disputa pelo próprio sentido de religiosidade no âmbito social cultural e político? (Burity, 2002, p.50).

R eligião, subj etividade e politização da vida e da sexualidade

A té aqui, limitei-me a expor o que pensam Rosado-Nunes, C. M ouffe e J. Burity sobre essas questões centrais para as atuais pesquisas, minhas e de outras pessoas, dentro desse marco teórico. A gora gostaria de me deter nas preocupações que me atingem em face das especificidades do meu objeto de pesquisa, e também com base nas questões levantadas por RosadoN unes e Burity, acima expostas.

A primeira observação a fazer é sobre a questão proposta por Rosado-N unes, em relação ao trabal ho da cultura moderna e de seus 
efeitos sobre a Igreja Católica. M ais especificamente o modo como a autora reconhece que esse efeito retorna à sociedade, na medida em que reapresenta o problema da autonomia individual, especialmente das mul heres, mas não exclusivamente delas, e das liberdades democráticas, coincidindo, assim, com as observações de Burity sobre o que chamei de relativização do público e do privado.

0 problema não se encontra em uma suposta necessidade de el aboração de um novo modo de conceber o reconhecimento da distinção entre o público e o privado, ou os seus limites históricos, mas de um questionamento pontual a esse respeito, na medida em que a I greja Católica e as outras igrejas são confrontadas em suas posições em relação ao feminismo, ao aborto, à homossexualidade e à eutanásia. É razoável pensar que a concepção tradicional de política não seja capaz de abranger, em certo sentido, as demandas por liberdade e igualdade aí presentes. Dworkin (2003) classifica as lutas pelo aborto e pela eutanásia como lutas pela liberdade individual. Essa individualidade tem características particulares que fogem a uma pressuposição liberal da política.

0 que a modernidade entende por liberdade e igualdade tende a ignorar dimensões da subjetividade, sobretudo aquelas que acabam trazendo implicações para o que se reconhece como "fundamentos universais do Estado democrático de direito", tais como o direito inalienável à vida. $M$ as também uma ordem social que pressupõe o que eu vou chamar de uma "determinada ordem de gênero", que até possibilita um certo sentido de igualdade entre os sexos, mas interfere, desfavoravelmente, sobre a autonomia da mulher, quando 0 assunto é 0 aborto.

0 segundo ponto a me chamar atenção refere-se à proposição de uma nova abordagem da distinção nós/eles proposta por M ouffe e outros autores. Se, na política tradicional, a construção de um "nós" e um "eles" tem um sentido de definir posições para, em seguida, tentar destruí-las através do primado da razão, no antagonismo democrático, essa construção assume um papel mais positivo: 0 de tornar possível uma democracia radical que reconheça o processo de conflito entre adversários que se confrontam, à semelhança de dois times de futebol, no qual, para que tal confronto tenha um sentido de jogo, busca-se o mútuo respeito às regras e, mais que isso, a construção de suas próprias identidades como uma conseqüência ou um desdobramento da existência do confronto com outro. Por exemplo, a identidade de vencedor. Também as paixões, e não só a razão, são reconhecidas como constitutivas nesse tipo de "jogo/democracia".

U m terceiro ponto importante seria a proposição de Burity em relação a mudanças no campo religioso expressarem um deslocamento do político para além da esfera estatal. Vimos, durante a exposição do pensamento de R osadoNunes, que a ênfase dada pela autora recai sobre o trabal ho da cultura moderna e de seus efeitos sobre a I greja. M as não resta dúvida que a própria Igreja Católica deslocou-se internamente, tanto política quanto teol ogicamente, em um movimento paralelo ao que ocorria na sociedade, de tal modo que as situações, no plano da cultura, complementavam-se, possibilitando as lutas que hoje presenciamos e que indicam valores e dimensões para além do Estado.

$M$ as o que é algo estar para além do Estado? Significaria algo à revelia deste? A lgo inalcançável pelo ordenamento jurídico? A lgo fora das políticas públicas? Certamente, nenhuma das alternativas. 0 ordenamento jurídico, assim como a execução de políticas públicas, é uma conseqüência de mudanças na esfera da sociedade civil que gera pressões sobre o J udiciário e cria as situações de necessidade de um novo ordenamento jurídico (Splenger, 2003; B rauner, 2003). Se tal ordenamento ainda não oferece leis adequadas às situações conflituosas, sejam elas em relação ao aborto ou em relação à sexual idade, ou a qualquer outra demanda, ou só parcialmente atendem a essas necessidades no espaço da sociedade civil ou do E stado, e, de igual modo, o Estado não executa políticas públicas que visem ao atendimento à população nas suas novas demandas no campo da saúde, por exemplo, é porque, no plano da sociedade civil, ainda não se formou um consenso, ainda que precário e conflitual, a ponto de mover a política a tais ações (M ouffe, 2003, p. 17).

Como temos sustentado até aqui, o principal sentido da expressão "para além do Estado" 
pode ser encontrado no fato de que a politização da vida e da sexualidade como aqui se descreveu aponta para um lugar do político não tradicionalmente objeto do Estado. U m lugar que se acreditava pertencente ao privado e, como tal, numa dimensão que antes se apresentava como consensual. A gora não. Se suponho que tenho 0 direito de optar pela morte em detrimento de uma vida atormentada por grande sofrimento e perda de dignidade pessoal, estou questionando, sim, o valor substantivo que tem a vida em nossa sociedade ocidental cristã e moderna. A chando eu que tenho o direito de interromper, por motivos fúteis ou não, a vida de um feto em qual quer estágio da gravidez, também me ponho na oposição do modo como valores morais, religiosos, jurídicos eideológicos são transmitidos e impostos ao conjunto da sociedade para fundamentar a argumentação, digamos, conservadora sobre esse assunto. A mesma coisa dáse em relação às mul heres e aos homossexuais.

E m quarto lugar, a questão da retomada da ética. De fato, politizar a vida e a sexualidade coloca-nos diante de novos desafios éticos, diferentes daqueles com os quais estávamos acostumados a tratar, no espaço de um cristianismo de libertação (Teologia da Libertação e outros projetos similares). A ênfase ali recaía na questão ética da desigual dade social, espaço politizado, mas exterior aos indivíduos. A qui temos que trilhar, no âmbito da ética, no caminho da subjetividade, sem deixar de nos lembrar que a politização aqui em foco pressupõe o político como constitutivo do social, o que, nas referências empíricas aqui expostas, acaba por apontar para novos significados em disputa do próprio sentido do religioso.

D workin (2003) refere-se a uma questão interessante, quando analisa o modo como as pessoas, de um modo geral, enfrentam a pergunta se são contrárias ou a favoráveis ao aborto. Para esse autor, o problema está no fato de que as pessoas pensam estar discutindo uma grande questão moral e metafísica - "saber se mesmo um embrião recém-fertilizado já é uma criatura humana com direito e interesses próprios" (Dworkin, 2003, p. 41) - e, sob essa suposta base, tomarem suas posições. 0 pressuposto, então, é de que o feto seja "uma criança não-nascida, indefesa diante do bisturi assassino do médico que vai fazer o aborto" (Dworkin, 2003, p. 41). A questão de natureza política não estaria, para esse autor, na compreensão das pessoas sobre se a vida tem um valor intrínseco desde sua mais tenra idade. $M$ as sobre 0 que Estado tem a ver com isso. Ou seja, se cabe ou não ao Estado interferir nas deci sões das mulheres em nome de um valor que se acredita intrínseco à própria existência material e espiritual do ser humano. Onde estaria, então, a liberdade individual?

0 impasse acima exposto poderia suscitar a pergunta: por que uma questão dessa natureza não diria respeito, prioritariamente "à política" e, sim, "ao político"? Não équestão de interessar prioritariamente "ao político" e, em segundo plano, "à política". M as o lugar de onde pontualmente se questiona a fal ta de liberdade ou a partir de onde atores sociais, individuais e coletivos sentem-se oprimidos. A democracia não está sendo aí posta à prova ou requerida como uma conseqüência da inexistência das estruturas do Estado democrático de direito, mas apesar dele! Para uma democracia plural radical e/ou agonística, o que é importante garantir é a existência e a liberdade de disputa pela hegemonia de novos significados de democracia. $E$ isto é um processo interminável, porque sempre haverá novas reivindicações e novos pontos nodais nos quais se estabel eçam lutas pontuais pela liberdade ou pela igual dade ou pela dignidade.

0 ético aqui apresenta-se como um parâmetro relativo a determinadas circunstâncias históricas e sociais, não cabendo um senti do fixo, fundacional e essencialista que regule a moralidade das relações de gênero ou homoafetivas. $M$ as isso não significa que, no cenário social, instituições diversas posicionem-se com discursos cujo pressuposto, para si mesmas, é de val ores universais, fundacionais e essencial istas. Pelo contrário, uma ética política da democracia agonística fundamenta-se, exatamente, na defesa intransigente da liberdade do outro de se expressar. 0 outro que lhe é oposto; até porque, do outro depende sua própria identidade. 


\section{Consider ações finais}

Iniciamos a nossa discussão sobre democracia neste ensaio restringindo-a a uma compreensão de democracia: a democracia agonística, que também pode ser chamada de plural radical (Torfing, 1999; M ouffe, 1996), uma vez que ela não constitui um projeto teleológico da política ou da história, mas uma estratégia de ação social que se reconhece inerente à própria feitura do social. Dissemos, também, tratar-se de uma compreensão de democracia que vê a si própria como contingente, na medida em que se pressupõe não ser possível um modelo ou um projeto de democracia que preencha, ou esgote em si mesmo, a plenitude de seu significado.

Partiu-se, também, da convicção de que a realidade social nas sociedades contemporâneas, mas não só nelas, está pulverizada por situações conflitivas, em que atores sociais diversos, pessoais ou coletivos, encontram-se em uma infinidade de identidades em construção e em busca de uma posição hegemônica para ali fazer surgir uma luta pontual pela democracia, desde que se esteja experimentando uma situação de domínio e de opressão. Essa luta acontece todas as vezes que um determinado conflito encerra, em si, uma disputa por um significado de libertação.

D efendemos, com M ouffe, a idéia de que um conceito tradicional da política, aquele que a limita às expressões de poder e de domínio do Estado, não se mostra suficientemente adequado para a compreensão da nossa real idade contemporânea, na análise dos conflitos inerentes ao social, sendo necessário recorrer a uma compreensão do que seja "o político" como categoria analítica dos conflitos sociais, exatamente por privilegiar as dimensões da sociedade civil, das posições de sujeito e dos discursos a eles inerentes, criando, assim, um "ambiente teórico" que abrigue o conceito de democracia agonistica.

Tendo como referência esse cenário teórico, procuramos estabelecer um diálogo com uma leitura da contemporaneidade da Igreja Católica e, por extensão, de outras igrejas conservadoras, com base nas considerações de Rosado-N unes, no todo de acordo com sua análise, mas acrescentando a proposição de que é necessário recorrer às categorias analíticas e à percepção da democracia agonística como um fenômeno inerente a uma sociedade realmente democrática, não só em seu sentido tradicional, mas também, e sobretudo, no sentido de garantir aos diversos atores sociais a exposição de suas demandas e de seus discursos em um processo conflitual, mas, ao mesmo tempo, contido em um princípio de regras a serem observadas por todos os participantes e implicados no confronto político.

Vimos que as profundas mudanças no campo religioso no Brasil, e certamente em muitas partes do mundo, tornam possível a percepção de que a religião vem se tornando um espaço da cultura onde novas demandas da subjetividade têm se manifestado, fazendo com que vel has posições e vel hos valores, que antes adormeciam em uma "harmonia celestial" no ambiente mais amplo de uma cultura católica, humanista e tradicional, fossem chamados à ordem do dia pela emergência de movimentos sociais que repropõem as questões feministas, homossexuais e da vida dentro e fora da I greja, em um patamar nunca visto antes, possibilitando um tráfego de influências mútuas entre as igrejas e a sociedade brasileira, e em luta pela fixação por novos significados da democracia.

Três outras noções para essa reflexão sobre a religião e seu papel nas sociedades contemporâneas são de fundamental importância para as temáticas aqui referenciadas como expressões do empírico aqui citado. São as noções de "deslocamento", "desprivatização" e "publicização" do religioso. A s duas últimas noções são o próprio deslocamento em si. M as é importante destacar a importância dessa "categoria" foucaultiana de deslocamento porque ela possibilita a compreensão do novo lugar que a religião, ou mais apropriadamente 0 religioso, passa a exercer em nossas sociedades. A compreensão dessa noção de deslocamento é, portanto, a chave hermenêutica para entender o que se quer dizer por "desprivatização" e "publicização" do religioso, na medida em que só através desses processos é que o religioso passa a se apresentar como o lugar do social em relação às questões aqui expostas. 
Em função desse processo acima descrito, é possível entender como se passou de um momento em que as questões relativas à ética e à política no espaço eclesial contemplavam aspectos do político que remetia à luta pelas liberdades democráticas próprias de um Estado democrático de direito e de justiça social, no campo e nas cidades, para outro campo: o campo da ética e da política, que se encontra marcado, também, e talvez predominantemente pela politização da sexualidade e da vida, requerendo de atores sociais e acadêmicos, institucionais ou não, novas respostas para novos conflitos. Isso nos leva à conclusão de que, de fato, o cenário religioso continua e, em outro sentido, tem se tornado um espaço do social muito importante para as questões que preocupam as pessoas no mundo real, no espaço da cultura, ena politização da subjetividade através de temáticas como o aborto e a eutanásia, e a mobilização de movimentos sociais, como os movimentos feminista e o GLBT.

Abstract: The text is about Chantal Mouf fe' $s$ concept of agonistic democracy. It focuses the place of the political characteristic of alture. It suggests as a consequence an analyses of social situation of the politizition of sexvality and life from the religious field.

K ey-words: democracy, religion, subjectivity.

\section{R eferências}

BRA UNER, M aria Claudia Crespo. Direito, sexualidade e reprodução humana: conquistas médicas e 0 debate bioético. Rio de Janeiro/São Paulo: Renovar, 2003.

BURITY, J oanildo. M udança cultural, mudança religiosa e mudança política: para onde caminhamos? In: BUR ITY, J oanildo (Org.). Cultura e identidade: perspectivas interdisciplinares, Rio de Janeiro: DP\&A, 2002. p. 29-63.
Caminhos sem fim - caminho do fim? M ovimentos sociais e democracia. In: FONTES, Breno (Org.). M ovimentos sociais, produção e reprodução de sentido. Recife: Editora Universitária da UFPE, 1999.

. Religião e política na fronteira: desinstitucional ização e deslocamento numa relação historicamente polêmica. In: Teoria \& sociedade (R evista dos departamentos de Ciência Política e de Sociologia e A ntropologia da U FM G), Belo H orizonte, n. 8, 2001.

- Identidade e política no campo religioso: estudos sobre cultura, pluralismo e novo ativismo eclesial. Recife: Ed. UFPE, 1997.

DOIMO, A na Maria. A vez e a voz do popular: movimentos sociais e partici pação política no B rasil pós-70. Rio deJ aneiro: Relume-D umará; São Paul o: A npocs, 1995.

DWORK IN, Ronald. Domínio da vida: aborto, eutanásia e liberdades individuais. São Paulo: $M$ artins Fontes, 2003.

FOU CA ULT, M ichel. M icrofísica do poder. Rio de J aneiro: Edições Grau, 1998.

LA CLA U, Enesto. M OUFFE, Chantal. H egemony \& socialist strategy: towards a radical democratic politics. London / N ew Y ork: Verso, 1985.

M OUFFE, Chantal. 0 regresso do político. Lisboa: Gradiva, 1996.

- Democracia, cidadania e a questão do pluralismo. In: Política e Sociedade - Revista de Sociologia Política, v. 1, n. 3, Florianópolis, UFSC, 2003.

ROSA D O-NUNES, M ariaJ osé. 0 catolicismo sob o escrutínio da modernidade. In: MUNIZ, B eatriz; MARTINO, Luiz M auro (Orgs.). Sociologia da religião e mudança social: católicos, protestantes e novos movimentos religiosos no B rasil. São Paulo: Paulinas, 2004.

SPE N G LER , Fabiana M arion. U nião homoafetivas: o fim do preconceito. Santa Cruz do Sul: Edunisc, 2003.

TORFING, J acob. New theories of discurse: L aclau, M ouffe end Zizeek. M alden: B lackw ell Publishers, 1999. 